\title{
English For Specific Purposes (ESP)
}

${ }^{1}$ Like Raskova Octaberlina \& ${ }^{2}$ Andi Asrifan (2021).

${ }^{1}$ Universitas Islam Negeri Maulana Malik Ibrahim, Malang, Indonesia

${ }^{2}$ Universitas Muhammadiyah Sidenreng Rappang

A R T I C LE I N F O

Points of Discussion

- English For Specific

Purpose (ESP),

- ESP area according to experts

- Types of ESP

- Characteristics of ESP

- The ESP Practitioner

- ESP Contents

- Is there a difference between ESP and EGP?

\author{
A B S T R A K
}

This paper discusses what ESP is to improve our English knowledge, particularly on ESP. The ESP is typically defined as a learning English approach focused on the learner's needs and expectations. English for particular purpose In Indonesia, in particular for students from outside the English department, the ESP approach is a common option for high school and university students. The use of this approach also fits into government education policies that emphasize the goals of learning English, specifically to improve students' ability to use English particularly for academic needs and careers, with a focus on reading skills that allow students to understand authentic subjects in different departments. The materials of teaching decide the contents of the course and affect teaching methods, encouragement of students, vocabulary and language function. The ESP aims to ensure that students can master English in the region they study. The assessment of the teaching materials helps teachers to develop the ESP topics constantly, adapting them to evolving needs of the students. A student needs survey and their assessment of teaching materials support the theoretical considerations. The results of the survey showed if the needs of the students were fulfilled during their ESP courses.

\section{INTRODUCTION}

In the 1960s language specialists commit themselves to providing new courses in order to satisfy the needs of the target population, annoyed by the shortcomings of general English courses, which made Target Situation analysis the driving goal of ESP courses following the inability to perform register analyses. The ESP is also a broader subdivision, which is a Language for Particular (Special) Uses (LSP), which Swales states is 'the field of language learning study and practice for people who need a language in order to fulfill predictable communicative needs.' It should be noted 1. The ESP was first developed and has continued to grow in response to a need: the need to use the language for a clearly identified functional purpose by non-native speakers. Robinson says: ESP'2 must do so as purposes shift. Pioneers in the area, Hutchinson and Waters have identified three major common explanations for the rise of the entire ESP: the demands of the Brave New World, a linguistic revolution and a new emphasis on the learner3. We should note that the ESP principle was not controversial in tracking the evolution of ESP.

The specificities of the language were treated as a lower level and isolated from the common language in the early 20th century. This led to studies by language experts and the discrepancies between specialist languages on the one side and the common language on the other. The situation later changed in the 60's and 70's of the same year, and the idea of specialized language was no longer treated as a device with no meaning, but as a communication method that was used in different contexts. Taking this into account, scientists concentrated on the linguistic aspect of the 
specialized languages and came to the conclusion that the key differences in the lexical aspect and in specific terminology are the most significant differences between a specialized language and the single language, as according to them, different specialization levels depend on In the 70s and 80s of the twentieth century, interest in specialized languages increased even further. In 1968, the British Council held the Special Languages Congress (LSP), a conference to address the problems of specific languages and hence the green light to specialized languages was given in the 1980s. In order to underline the specific linguistic needs of students, the name was changed into languages for specific purposes. At that time, Elsevier started publication of her journal English for Specific Purposes, which was distributed in the publishers' catalogs and many ESP books and articles. As a result, from the late ' $80 \mathrm{~s}$, various scientists and research centres, because of the multitude of names given to the specialized vocabulary we today call, were searching for the right terminology to describe the field of study. The different names that apply to LSP include specialized languages, specialist communication, technical english, science english, english for special and/or special purposes - ESP, english for professional or latest professional purposes.

\section{A. Definition of English For Spesific Purpose (ESP)}

ESP tends to be very versatile and different people have different meanings. As many as the number of language users who have identified it can be counted. All these concepts seem to cover different features of this approach (Sifakis, 2003 cf. Rogers, 1989; Rogers, 1996). In "The Japan ESP Conference," which was organized by Aizu Universidad, Aizuwakamatesu on November 8th, 1977, Anthony (1997, p. 1) listed the "clear difference in how people interpreted ESP in terms of meaning," he said. He pointed out that the participants have been divided into two classes.

This has been described by Robinson (1980) as English learning for students with specific goals and objectives, which according to him may be technical, academic, science, etcetera, or as teaching English for "clearly utilitarian" purposes by Mackay and Mountford (1978, p. 2).

\section{Absolute Characteristics:}

ESP consists of English language teaching which is:

- Designed to meet specified needs of the learner;

- Related in content (i.e. in its themes and topics) to particular disciplines, occupations and activities;

- Centred on the language appropriate to those activities in syntax, lexis, discourse, semantics, etc., and analysis of this discourse;

- In contrast with General English.

II Variable characteristics:

ESP may be, but is not necessarily:

- Restricted as to the language skills to be learned (e.g. reading only);

- Taught according to any pre-ordained methodology (Gatehouse, $2001 \mathrm{cf}$. Strevens, 1998, pp. 1-2).

In comparison to general English, this description aims to define ESP. The emphasis is therefore on "specific English," which is part of those disciplines, occupations or activities. The ESP training is required in the description to focus on the language that is suitable to some discipline, profession or operation, i.e. syntax, lexis, discourse, semantics etc. A updated description of ESP, consisting both of absolute and variable features of ESPs as follows was submitted by Dudley-Evans and St. John (1998, p. 4-5): 


\section{Absolute Characteristics}

- ESP is defined to meet specific needs of the learner;

- ESP makes use of the underlying methodology and activities of the discipline it serves;

- ESP is centered on the language (grammar, lexis, register), skills, discourse and genres appropriate to these activities.

II Variable Characteristics

- ESP may be related to or designed for specific disciplines;

- ESP may use, in specific teaching situations, a different methodology from that of general English;

- ESP is likely to be designed for adult learners, either at a tertiary level institution or in aprofessional work situation. It could, however, be for learners at secondary school level;

- ESP is generally designed for intermediate or advanced students; Most ESP courses assume some basic knowledge of the language system, but it can be used with beginners".

This definition also recognizes that ESP is intended to meet the needs of the learner but excludes the attribute stated in Strevens' definition that "ESP contrasts with English in general." This revised definition has broadened the ESP horizon by encouraging students who do not generally belong to a particular field or discipline to cover their individual needs. The list of variable features has also been expanded by Dudley-Evans and St. John (1998). They argued that "the ESP may be linked to specific disciplines or designed to meet the needs of specific teaching situations in particular disciplines" and various methodologies "from that of general anglais," not always appropriate (ibid.). DudleyEvans and St. John believed that ESP courses "will probably be for adult learners" but could be arranged 'for high school students,' in contrast to the perception of limiting ESP coursework for adult learners (Abbot, 1981; Widdowson, 1983; Robinson, 1991; McKay and Tom, 1999). They also found out that ESP courses with intermediate or advanced students can be arranged for beginners. As Hadley (2006: 3) pointed out, the above discussion notes that " $\mathrm{S}$ " in particular is important for this approach: "the secret to ESP's teaching is to focus directly on "S." By its concern for specialized language and practice ESP can be distinguished from general ELT." But the term "special" may be used for a specific language or special requirements/objectives. In the 1980s, this misunderstanding regarding both definitions had been identified (Gatehouse, $2001 \mathrm{cf}$. Perren, 1974). The concept of a special language is defined as the following by Mackay and Mountford (1978, p. 4): "The only practice in which the notion of a special language is understood is as a limited list of words and terms from the entire language, for this restricted vocabulary involves any need within a well-defined setting. Instead of the essence of the language they wanted to learn to speak, the second idea, the "special aim," was to understand English as a second language (ESL) or English as a foreign language (EFL) (ibid.). The first notion and ESP was endorsed by the Barron (1994, p. 3), who insisted on "fixing ESP firmly into the multidimensional space that constitutes the disciplinary culture selected by students." Moreover, "social, cultural or political factors as well as functional" factors were clarified in the multidimensional space (ibid., p. 3). The principle of "EPS" was endorsed by Strevens (1998), because "unlike general English" is one of the absolute characteristics of its name. As a result, ESP should reflect on the specific needs of students and events in particular. Fiorito (2005, p. 1) supported this conviction and said that "the ESP focus is on English, not being taught as a subject apart from the real world of students (or wishes), but being integrated into an important 
subject for learners."

This restricted perception of the scope of ESP was refuted by Dudley-Evans and St. John (1998), including in the ESP reimbursement, English for academic purposes (EAP). They further explained their point that "it is our argument that all courses in specialized language and practice are subject to english for specific purposes" (Hadley, $2006 \mathrm{cf}$. Dudle Evans and St. John, 1998, p. 3). This specialist means business, academe, technical, etc. (language and practice). The concept of ESP was also favoured by Hutchinson and Waters (1987) and was not limited to any particular discipline. They were theorizing that "ESP is a language teaching approach in which all decisions concerning content and methods are based upon the learner's reasons" (ibid., p. 19). They believed that ESP programs insisted that "a learner has a reason to learn and not a profession or occupation," and that "the word 'special' in ESP should therefore be focused on this matter." Gatehouse (2001, p. 3) said:

Even though it appears that a vast majority of ESP advocates believe that ESP is a very versatile approach to English as a second (TESL) / English as a Free Language (TEFL) teaching which, as well as special discipline, is central to, but also provides an opportunity for, the meaning and scope of ESP (Barron, 1994, cf. Widdowson, 1983, pp. 108-109).

\section{B. ESP area according to experts}

a) Hutchinson and Waters' (1987) metaphoric classification: the tree of ELT

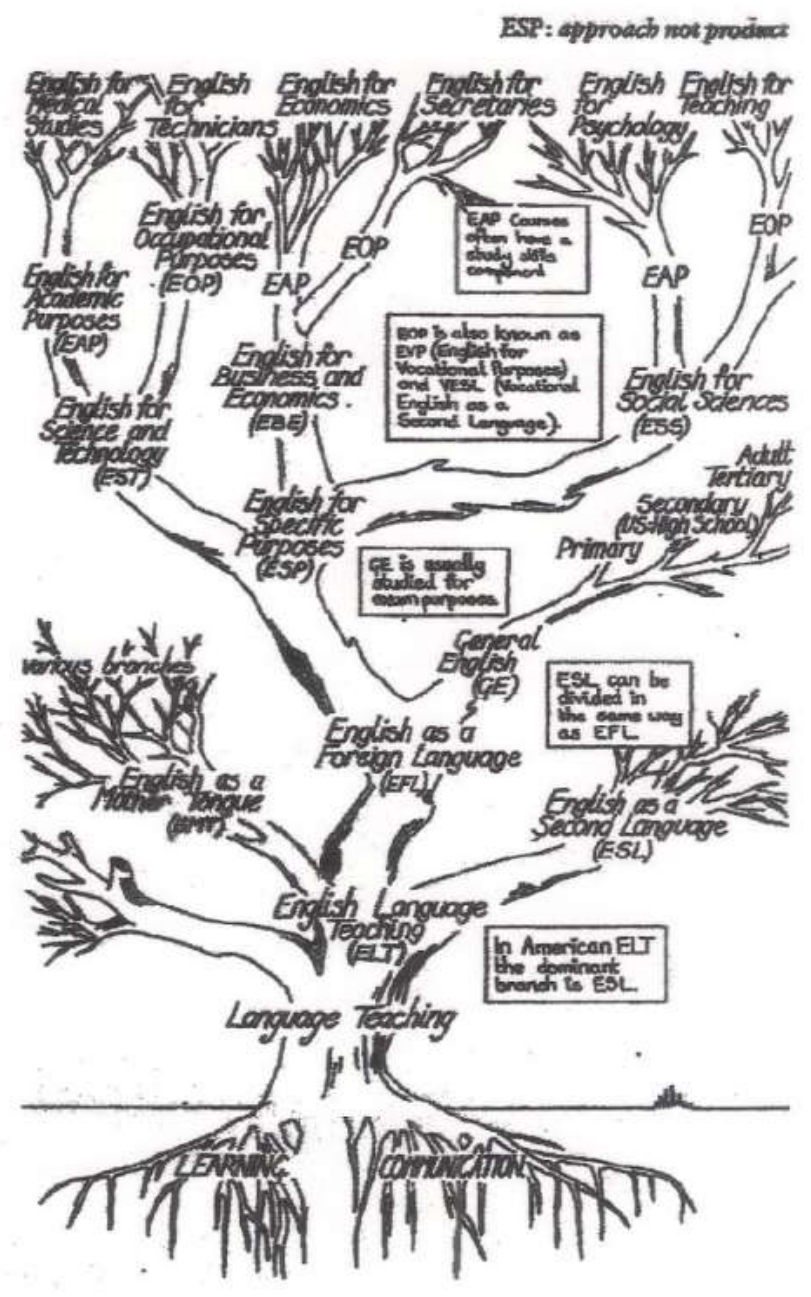


b) Robinson's (1991) classification

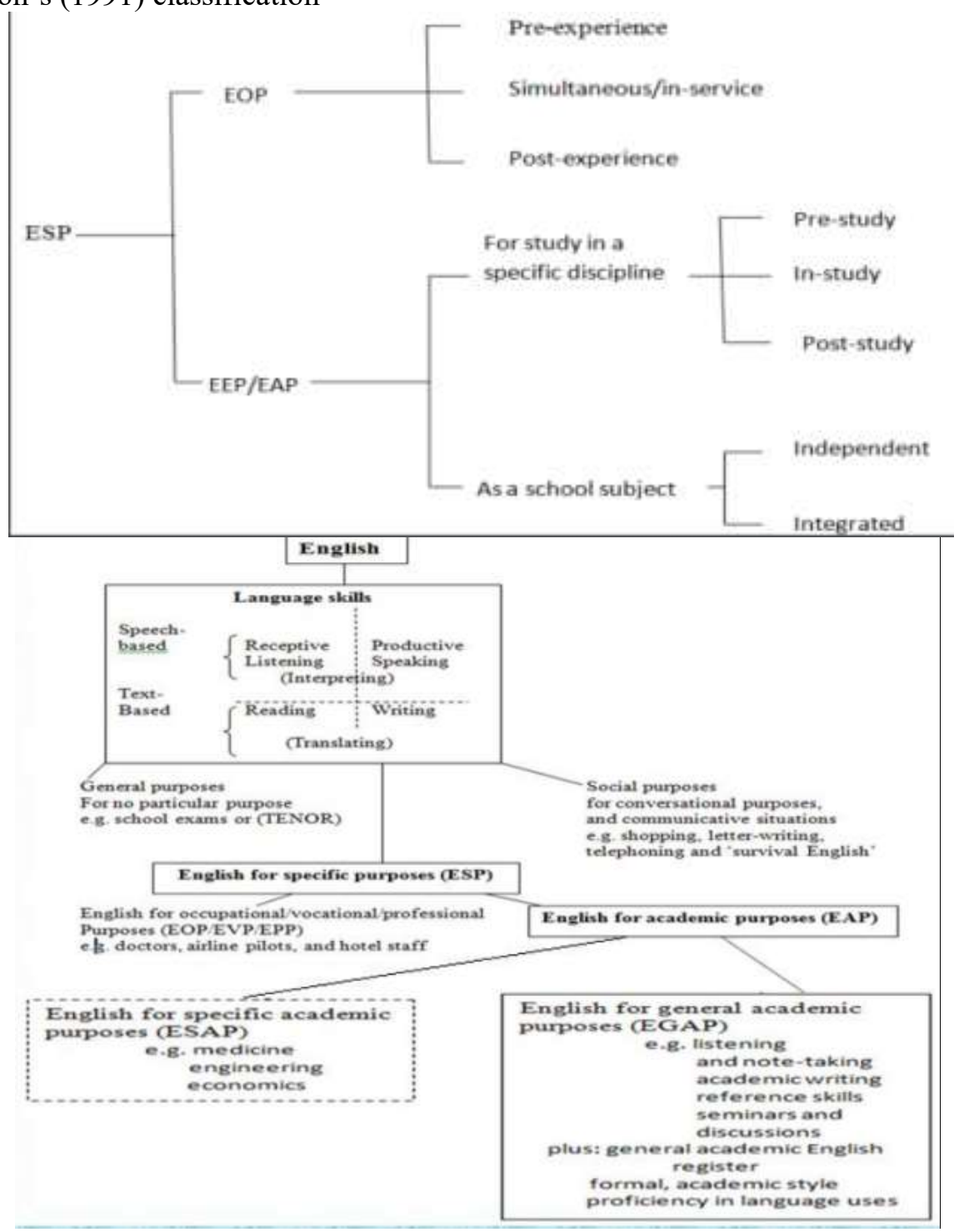

c) John's classification in the USA

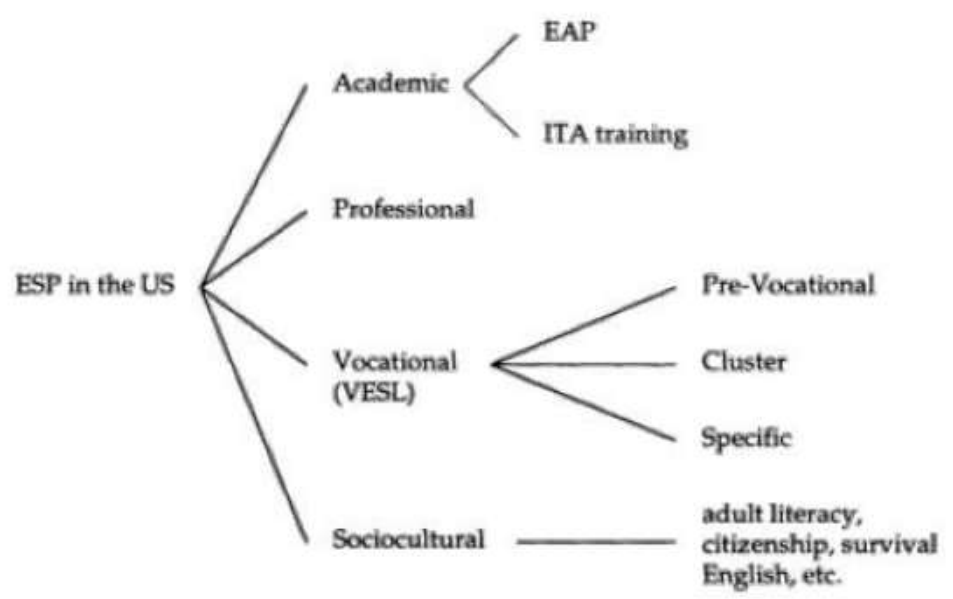

English for specific purposes in the United States ( Johns, 1990 ) 
d) Howrd's classification of ESP

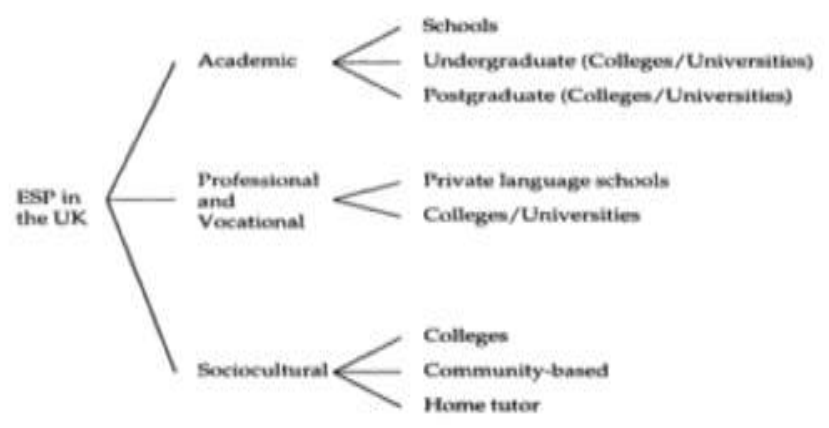

English for specific purposes in the United Kingdom

\section{Types of ESP}

EAP is divided into two Categories by Dudley-Evans and St. John, (1998): General Academic Purposes English (EGAP) and ESAP. EGAP has to do with teaching language skills common in various disciplines, but ESAP refers to the teaching of language skills unique to different disciplines. Investigation has provided insight into the EGAP and ESAP reciprocal relations. EGAP programs can pass to specific disciplines the skills and language features acquired from ESAP programs (ibid.). Many researchers addressed ESP forms and most of them divided ESP into two major categories: Occupational English (EOP) and the EAP (Hutchinson and Waters, 1987; Robinson, 1991). Carter (1983) defined three types of ESP: 1. Limited language English 2. Academic and job (EAOP) English 3. Relevant English subjects.

The definition of "limited language" was clearly established by Mackey and Mountford (1978) in his statement: "... In the sense that the repertoire required by the controller is strictly limited in nature and that the situation is accurate in determining the linguistic needs of a waiter dating or air hostess, a language for international airtraffic control may be considered 'unique' But these small repertoires are not languages, just as the book is not a tourist term. The speaker does not interact effectively in new circumstances or in contexts outside of the vocational community if they know a small 'linguage'"'" (Gatehouse, $2001 \mathrm{cf}$. Mackey and Mountford, 1978, pp. 4-5). This first form of ESP is very restricted in nature and scope, which helps students to learn the language of English for very limited purposes and for the study of unique circumstances. This kind of ESP instruction is restricted to "a limited selection of phrases and phrases and these students are unable to use the language in any situations other than those for which they have been taught. Carter (1983) has recognized EAOP as the second form, although most other researchers have confined their grade ESP to EAP and EOP.

It seems that the ESP has been distinguishable from the EOP and the EAP due, ultimately, to the scientific and technical information that ELT was to be transmitted to non-Englishspeakers through this modern method (Hutchinson and Waters 1987; Gatehouse 2001; Dudley). Kennedy and Bolitho (1985) added the English language for science and technology to their list of ESP forms. 


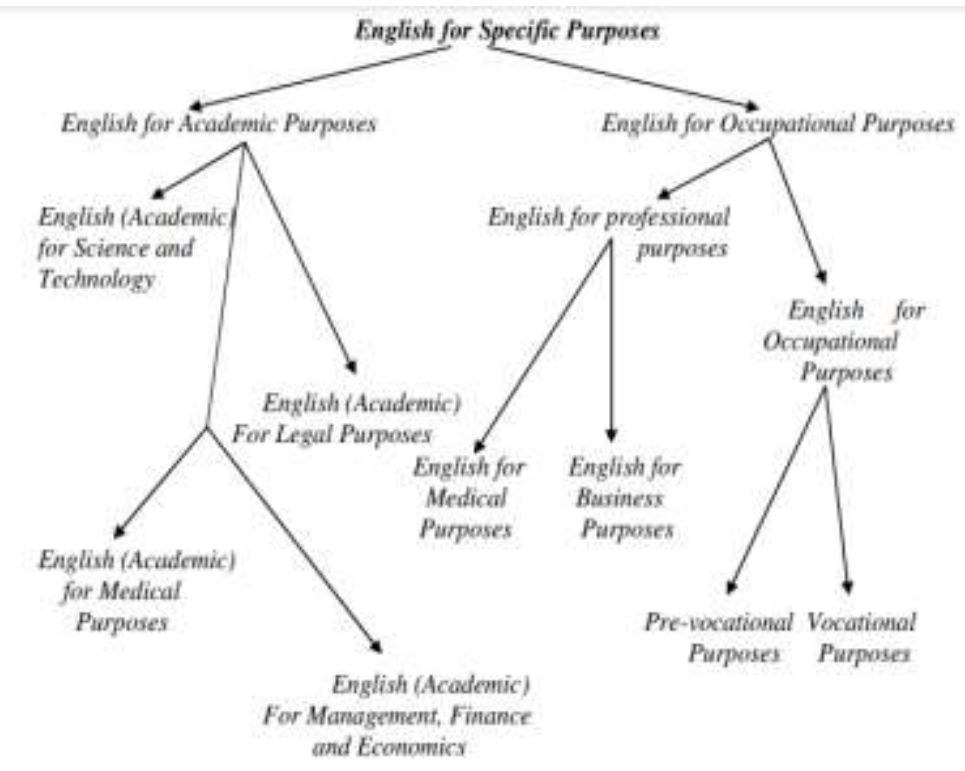

In Carter's view of EOP and EAP as not completely different phenomena, the organization seems to agree with Hutchinson and the Waters party (1987). They argued that "people can work and study simultaneously and that in many cases, when the student takes up or returns to a job, language learned for immediate use will be used later" (ibid., p. 16). What follows from the above debate is that the EOP and the EAP have approximately similar aims, but their dynamics and means are indeed different to the ultimate goals. Also, the EAP and the EOP were included by Dudley-Evans and St John (1998, p. 5). The classification you suggested is as follows:

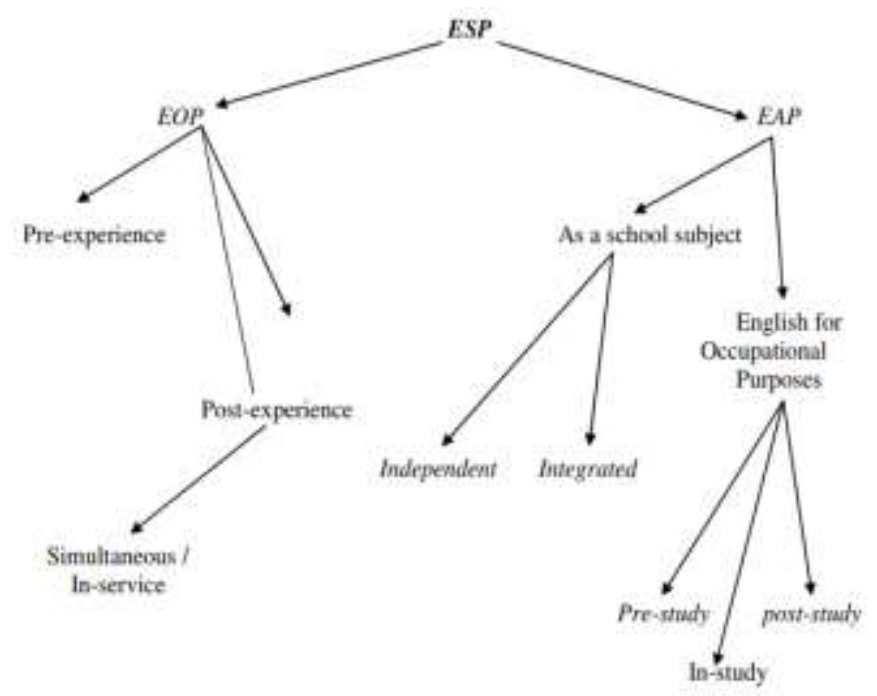

The third form of ESP according to Carter is English with unique themes (1983). He spoke about events such as postgraduate reading studies, international institutions and conferences as potential scientific needs. This 3rd category of ESP allows students to clearly define their language needs before developing ESP materials. It is limited to the future (language) needs of students (TFNs) in order to train them for their future needs. It seems that the ESP category is not distinguishable because every ESP course has an acceptable NA method, as a component integral to the creation of the ESP instruction material aimed at the language of the situation, including topics listed by Carter (1983) and elsewhere (Gatehouse, 2001).

\section{Characteristics of ESP}

The researchers who discussed ESP's characteristics do not seem to be in disagreement with this particular problem and most of them support the key characteristics suggested in Carter 
(Strevens, 1988; Bojovic, 2006; Dudley Evans, 1997; Gatehouse, 2001) (1983). "A) authentic content, b) purpose-related orientation, and c) self-orientation are the features widely used for ESP courses (Gatehouse, 2001 cf. Carter, 1983, p. 2). 'Authentic content' means that the student's principal field of study, or his career, is used by material that is not produced or published for teaching purposes. This content may include books, forms, maps, graphs, etc., and these genuine text forms may be used, according to the teaching conditions, in amended or unmodified forms. If ESP courses are offered at advanced or sporadic level as DudleyEvans proposes, authentic materials would be an acceptable choice; (1997). "ESP is indeed a function, especially in self-management research and research tasks, of using authentic materials, modified or unmodified in shape" (Gatehouse, 2001, p. 4). He also stated that students whose language was taught in health services were evaluated primarily through numerous independent study tasks in their chosen domain.

Students were encouraged to use different tools to carry out their study tasks. The goal orientation (Gatehouse, $2001 \mathrm{cf}$. Carter, 1983) was found to be a simulation of various communication activities in order to train students for various target situations. The students are practiced in a simulation way to manage different language positions in the target situation. Carter (1983) recorded simulating various tasks needed for a conference by the students. The activities included writing documents, reading papers, taking notes, etc. Students were instructed to design and create unique companies such as "market research, pamphlets and logo creation" in EBP course at Algonquin College and all of their final products were presented through a poster presented session (Gatehouse, 2001). He told about his Institute's work in the field of health science. The students exercised listening skills and "went to a local community center with newly acquired skills, and partnered with English speakers" (ibid., p. 4). Another example was the Faculty of Agricultural Studies in Cacak, where "students were involved in presenting a particular agricultural product, creation of a logo, negotiations with their customers (suppliers and purchaser), telephone conversation" (Bojovic, 2006, p. 3). The third feature of ESP courses is "self-direction" which means that ESP is interested in making students users" (Carter, 1983, p. 134). This means that the students should be "free to decide when, what, and how to study" (Gatehouse, 2001, p. 5).

\section{E. The ESP Practitioner}

We start to see how common the ESP is, if we embrace the above definition. In reality, the question is, 'How is the ESP' approach different from 'General English?' 'Hutchinson et al. (1987:53) respond very clearly, 'Nothing in theory, a ton in reality.' The last declaration was obviously valid in 1987. At that time teachers of 'General English' courses would rarely perform a need analysis to figure out what was required to actually accomplish it, while recognizing that students had a particular reason for learning English. However, teachers are now much more conscious of what requires research is, and published textbooks have significantly changed to allow the teacher to choose materials that fit closely with students' goals. This may be evidence of the impact on English language teaching in general from the ESP method. The difference between stopping 'General English' and beginning of ESP courses is nevertheless quite ambiguous. Ironically, though many 'general English teachers' can be represented using the ESP approach, building their syllabus on an examination of student needs and their own experience in using English to allow genuine communication. ESP teachers are not generally able to rely on personal experience when reviewing materials and considering course targets from a perspective unrelating to the discipline in which they are invited to teach. In particular, they cannot rely on the views of the students at the university level who seem to not know what English skills the career they wish to join demands.

As a result, many ESP teachers are slaves to available published textbooks and, worse than anything, they are prepared to teach from textbooks that cannot be properly adapted to a certain topic when there is no textbook available. The real ESP instructor (Swales, 1988) is 
defined as five different roles by Dudley Evans. There are: (1) teachers; (2) employees; (3) designers of courses and suppliers; (4) researchers; ( 5) appraisers. As a "teacher," the first part is synonymous with that of the teacher. Differences between the two occur in the performance of the other four positions. The ESP practice member must first work in close collaboration with field experts to address the individual needs of students and follow the curriculum and the activities of the target discipline. Orr reports an example of the substantial effects of such a collaboration (1995). However, this partnership does not stop in the creation process and may expand a possibility discussed by Johns et al as far as teaching is concerned (1988). If teaching by teams is not a choice, the ESP Practitioner needs to cooperate closer with the students, who normally are more familiar with specialist material than the teacher. Teachers of 'general English' and ESPs also need courses and resources to be planned. The specificity of these materials is one of the big controversies in the field of ESP. Hutchinson et al. (1987:165) support materials covering a broad range of areas which claim that the grammatical structures, roles, structures of expression, capacity and strategies are similar in different disciplines. However, more recent research has shown that this is not the case.

For instance Hansen (1988) explains clear differences between texts on anthropology and sociology, and Anthony (1998) introduces specific features of engineering writing. Unfortunately, with the exception of the textbooks for major areas, including informatics and business studies, much of the content is repetitive and maybe even confusing about what is right in the target sector, using topics from many disciplines. Consequently, many ESP practitioners have no choice but to produce original materials. The role of the ESP practitioner as a 'researcher,' with findings that directly lead to appropriate materials for the classroom, is particularly relevant here. The ultimate position as 'evaluator' is probably the role most overlooked to date by ESP practitioners. There were few observational research to assess the efficacy of ESP courses, as Johns et al. (1991) explain. The only appraisal, for example, of Hall et al. (1986:158)'s no-mandatory course is that, "students continue to attend despite rival pressures of a heavy programme of credit courses" Recent papers like Jenkins et al. (1993), on the other hand, indicate that there is a growing interest in this field of study.

\section{F. ESP Contents}

An extremely important area of discussion among ESP researchers has been the inclusion of specialized contents in ESP courses. The first phase of ESP that lasted till the beginning of 1960 's, confined itself to the teaching materials consisted of authentic texts in different fields of specialization (Hutchinson and Waters, 1987). Furthermore "S"that stands for "specific"suggests that ESP "can be differentiated from general EFL/ESL by its concern with specialized language and practice"(Hadley, 2006, p. 3). Wales (1993, p. 4) presented the following "specific factors of pedagogical concern"while discussing the reasons of including general English in workplace (ESP) courses. "They are:

1. That there are linguistic relationships between general and specific English.

2. That learners' perceived needs may include general as well as specific English.

3. That learners' L2 proficiency level may require general skill development".

St. Johns and Dudley-Evans (1991, page 307) argued that "All language and practice course" was included in ESP. "Where a subject such as pharmaceuticals or computing is taught in English, it is not ESP teaching itself; it is happy teaching. ESP must have both language teaching and language skills - EGAP - ESAP" (Dudley-Evans, 1997, p. 9). An integral component of any ESP program will appear that the content of target subjects is included. "The content of the teaching materials should be relevant to their needs and should provide students with new information" (Chantrupanth, 1993, p. 9). His experience in designing the ESP course for nurses in Miyagi University (1997) is clarified by Adamson (p. 65). He also concluded that "ESP is a workable and preferable approach to language teaching via content." Special content of subjects serves a variety of objectives, which "sometimes encourage learners to understand the conceptual elements underlying the language" (Cozens, 2006, p. 7). $\mathrm{He}$ gave a clear insight into those teachers who did not want to include the subject matter. He 
assumed that the basic needs of all learners should be addressed by a "functional academic program" or "general language" programme. Gunawardena and Knight (1989) addressed the negative attitude of students towards general English courses at Sri Lankan Universities in the Engineering and Medical Departments. He submitted that "students feel that the study of 'general English' is time-consuming and have little or no tolerance of material outside of their area of study" (ibid., p. 112). The following is the same approach: The following:

Tertiary languages are also viewed as topics of secondary importance. The attitude of students towards language as a faculty subject is reflected in the situation and is not related to what they perceive to be their real program of study (Cozens, $2006 \mathrm{cf}$. Gvardjancic, 2001, p. 8). Several research studies have also shown that the motivation of students is impaired by ELT courses not involving subject matter. For a first year introductory course in art history at a leading Japanese university, Peters and Saxon (1997: 108) gave insights in their experience in designing content-based units and concluded that "content-based English lessons can provide a meaningful environment for English-language development." Sagliano et al. (1998) have interpreted their observations and proposed to include unique content in instructional material from the ESP. Even though the role of an ESP practitioner should not be limited to the content of the lecture only, and research showed that it is not restricted to the interpretation of the students, but also affects the other faculties and the administrative staff (Cozens, $2006 \mathrm{cf}$. Smoak, 2004, p. 8). Also, Cozens (2006: 10 cf. Davis, 1979) has warned against the "danger of a fully content based course on learners' health." This curriculum is strictly limited to the specialized subject content. He provided the example of a protein-only anteater in an English zoo, indicating that language students needed "experience beyond the language learning room to give the skills they needed to use English in a natural environment" (ibid.: 10). Also stated by Hutchinson and Waters (1987) is that ESP does not only teach advanced English languages. The "relevant lexical objects" form part, as it were, of an ESP course and the practice of the term "division into three classes: technical, subsocial and nontechnical" was suggested by Bejan (1989, p.94).

This seemed a valuable insight into the fact that an ideal ESP course could balance these two extremes: general English courses and language courses that are purely content-based. Gatehouse (2001) has indicated the need for the students to cope with a communication situation that is directed at their work: the ability to use specific jargon, the ability to use university or business skills in general and the capacity to communicate in some other social context. An ESP course that includes the topic material and general English would effectively fulfill this detailed objective. Fiorito (2005, p. 2) argued that "ESP combines the subject and teaching of English." He concluded that this mixture is highly motivating, as it helps students in their field of specialisation to apply what they studied. Gulzar \& Sutana (2009, p. 123) stresses the importance of the evolution and impact of ESP curricular curricles in EFL/ESL classrooms in the sense of classroom discourse to understand the pedagogical teaching of the classroom and the interaction of teachers and students. For the success of the ESP courses, this activity is crucial. Another added advantage of the subject matter is that the ability of students to learn various language functions taught to them by these semi-content-based ESP courses in their specialist field improves. The "How much" and "what" the content of an ESP course is expected to include is unresolved and can only be decided by the students' needs. A correct NA must determine the percentage of specialized and general English content. Hutchinson and Waters (1987, p. 59) argued, if students, sponsors and faculty are aware why the learners are getting English, that knowledge of what is appropriate in language courses as fair contents and what ability is to be exploited on the positive side.

NA plays a major role in separating ELT from ESP. ELT is equally essential for all four language skills, while NA distinguishes for an ESP course, which language skills/competences should be prioritized for others according to the unique needs of the students. An ESP may be structured to improve learners who study in a business management graduation course or may focus on the improvement of speech skills of students who attend 
the course to become tourist guides (Fiorito, 2005). A balanced ESP course also helps students to prove that their perceived needs have been met, and reassure them that the language classes are relevant and important to their ultimate purpose - in summary, the questions are not perfectly answered (Cozens, 2006, p. 14). The above discussion would seem to suggest that a practical NA-based combination of specialized content and general English is necessary for the particular needs of students and for the intent of an ESL course to be and should be to enhance their interests and motivation.

\section{G. Is there a difference between ESP and EGP?}

The response to this question is very plain, according to Hutchinson and Waters, 'in theory none, in reality abundant.' They said: 'It is not a condition that distinguishes an ESP from an EGP, but a consciousness of the necessity'3. Pauline C. Robinson describes ESP as an ELT type and defines it as a "goal-oriented language learning,"4 which means the student must accomplish those goals. Basturkmen said ESP courses have a lower emphasis on students' needs analysis than general ELT courses. ESP courses concentrate on job or research needs, not individual needs or general interests'5. Basturkmen notes that "In ESP students, who engage in scholarly, professional and research work, and use English as a means of conducting such an effort, are seen to be language learners. External targets advocate an instrumental view of non-linguistic language and language learning. Targets are usually linguistic for ELT situations (eg, development of oral competence or broad vocabulary, or the ability to use a variety of grammatical structures). It is right to remember in an ESP that the student needs to achieve 'real world' goals and that they need some linguistic ability targets'6. In his ESP Instructor Paper: Issues, Tasks and Challenges7, Mohammad Kaosar Ahmed strongly supported his idea. Thomas Orr says 'English for general purposes' in junior and senior high schools is simply education English. Students learn the sounds and symbols of English and also the lexical/graphic/rhetorical elements which make up the lectures spoken and written. The line between ESP and EAP clarifies that 'English for Specific Purposes (ESP) is an EGP-built study and teaching designed for the training of students or adults who work for English and use in the fields of science, vocations or certain careers.... University teaching that presents common characteristics to students.

ESP is both a scholarly debate, often referred to as EAP in science or science. The ESP definition of English for specific purposes is described as following. It essentially focuses on all language aspects relevant to a specific field of human activity and takes account of students' time constraints. The ESP is the language learning concept. It can therefore be inferred that EGP is basic language learning which has previously been studied but not during college or university. English should be more advanced, more specialized in the university or college, and of course tailored to the specialization of a student. In contrast to EGP, ESP increases the enthusiasm of students in their specialization and their needs. Just as Hutchinson and Waters said 'learners know why they study the language in particular' so the enthusiasm of students enables educators to respond more easily to their needs and expectations. Anthony states, however, that the line between the stopping of "the General English" course and the beginning of the ESP course is quite confusing. Many 'General English' teachers can be identified by the ESP approach and by using English for real communication to base their curriculum on the student requirements and their own unique information and many of the 'ESP teachers' take the most remote approach outlined above. ESP teachers who are not connected to the subject in which they would teach are not generally not dependent on personal knowledge in the assessment of materials and research goals. They also cannot rely on the opinions of students in particular at university level who are not sure what English skills are needed for the career they wish to join. As a consequence, many ESP teachers become slaves in publishing ready-to-read textbooks. If no book for a specific discipline is available, they decide to teach in textbooks which do not suit them very well.

In summary all the items mentioned in the paper, ESP develops knowledge of potential 
problems for students, either academics (if they want to pursu a science career) or a job compared to General Purpose English. ESP thus includes the academic English language and the technical English language. The goal is to introduce students to the basic communication needs for their future university and professional community5 according to Kay Westerfield, a renowned ESP publications practitioners, and we, university lecturers, are highly supportive of this view. English is the only academic language. We had to design courses for this objective, to correctly formulate research targets that are unique to the discipline we are teaching, spend a great deal of time looking for authentic materials/texts and difficult tasks in order to understand and evaluate. To achieve a well-designed course one needs to integrate different components of Academic English. On the one hand there must be no forgetfulness in specialist terms or scholarly writing. University students take part in conferences, seminars and workshops both domestically and internationally and need the requisite oral and written skills. In such cases, students are able to demonstrate their language skills. It is more geared to the urgent needs of the students in English for occupational purposes. This bases primarily on advanced vocabulary, phrases and techniques related to incomprehension and incomprehension. The exact material is given to resolve the issues in the workplace. Kay Westerfield said, in the interview quoted above, that EAP classes provide particular support to the undergraduate and post graduate disciplines of the upper division. Our primary objective is to enable students to work properly in the target situation. An ESP course therefore needs to be target-driven, learner-driven and situational. We can only assume that we have grasped the meaning of ESP in line with these three requirements.

\section{CONCLUSION}

ESP refers to English teaching in academic or vocational studies, or English teaching to non-native English-speakers studying English for a particular reason. The expert is the product of his research in order to create certain meanings but the same purpose. In summing up all described in the present paper, ESP develops understanding of its future problems, whether it's academic (if it's science) or work, as opposed to English for a general purpose. ESP thus includes the academic English language and the technical English language. The goal is definitely to introduce students to the specific communications needs of their future academic and professional discourse, and we university lecturers strongly support this view, according Kay Westersfield, a well-known publishing professional in the ESP field.

\section{BIBLIOGRAPHY}

Abbot, G., 1981. "Encouraging communication in English: a paradox"ELT Journal (35, 3), pp. 228 230 Retrieved http://eltj.oxfordjournals.org/cgi/pdf_extract/XXXV/3/228

Paltridge, B., Starfield, S., Ravelli, L. \& Tuckwell, K. (2012a). Change and stability: Examining the macrostructures of doctoral theses in the visual and performing arts. Journal of English for

Davis, R., 1979. "All protein and no roughage makes humid a constipated student", In: English for Specific Purposes (Holden, S), eds; Modern English Publications Ltd.

https://www.researchgate.net/publication/323254539_The_Essence_of_English_for_Specific _Purposes.pdf

Strevens, P. (1988). ESP after twenty years: A re-appraisal. In M. Tickoo (Ed.), ESP: State of the art (1-13). SEAMEO Regional Language Centre Khoey, Key Issues in English for Specific Purposes (ESP) Curriculum Development, Absolute and Variable Characteristics of ESP,

Anthony, L. 2000. English for Specific Purposes: What does it mean?Why is it different?The Internet TESL Journal, (Online), Vol.VI, No. 3,

http://www.ikiu.ac.ir/public-files/profiles/items/090ad_1425402410.pdf

Johns, A. M., 1989. "Some comments on the nature of Chinese ESP Course books". In: ESP 
in

Practice (Peterson, P. W.), eds; English Language Programs Division, United States Information Agency. Washington, D. C. pp. 85-90.

https://www.researchgate.net/publication/266496006_Defining_English_for_Specific_Purpos es_and_the_Role_of_the_ESP_Practitioner

Strevens, P. (1988). ESP after twenty years: A re-appraisal. In M. Tickoo (Ed.), ESP: State of the art (1-13). SEAMEO Regional Language Centre Khoey, Key Issues in English for Specific Purposes (ESP) Curriculum Development, Absolute and Variable Characteristics of ESP,

Sifakis, N. C., 2003. "Applying the adult education framework to ESP curriculum development: an integrative model", Science Direct, English for Specific Purposes, 22(2), pp. 195-211. Retrieved http://www.sciencedirect.com/science?

Gatehouse, K., 2001. "Key Issues in English for Specific Purposes (ESP) Curriculum Development", The Internet TESL Journal, 7(10), Retrieved $\backslash$ http://iteslj.org/Articles/Gatehouse_ESP.html

Hall, D., Hawkey, R., Kenny B., \& Storer G. (1986). Patterns of thought in scientific writing: A course in information structuring for engineering students. English for Specific Purposes, 5:147-160.

A.Pichardo, Nelson. 1997 New Social Movement 'A Critical Review'.California: Annual Review of Sociology. Vol. 33.

Abercrombie, N., S. Hill and B. S. Turner. 2000. 'Social structure' inThe PenguinDictionary of Sociology, 4th ed., Penguin, London, pp. 326-327.

Abercrombie, Nicholas, 2010. Kamus Sosiologi. Pustaka Pelajar: Yogyakarta

Aberle, David F. 1966. A Classification Of Sosial Movement.Chicago: Aldine Publishing Aberle Co

Adaby, Ahmad, Darban dan Mustafa Kemal Pasha.2000.Muhammadiyah sebagai Gerakan Islam (dalam perspektif Historis dan Ideologis) Yogyakarta : Pustaka Pelajar,

Agustang. A. (2011). Filosofi Research (Dalam Upaya Pengembangan Ilmu).

Agustang. A. (2015). Dasar-Dasar Filsafat Penelit(ian Untuk Pengembangan Ilmu (Idham Irwansyah Idrus (ed.); Pertama). CV Multi Globa, Jalan Maccini Sawah No. 251.

Agustang, A. (2011). Pendekatan Penelitian Kualitatif dan Kuantitatif Suatu Tinjauan Kritis. Makassar: Andira Publisher.

Agustang, A. (2007). Entaskan Kemiskinan: Analisis Kinerja Pembangunan Indonesia. Makassar: Indobis Publisher.

Agustang, A. (2018). SIMBOLIKHAJI: Studi Deskriptif Analitik pada Orang Bugis. AlQalam, 15(2), 317-334.

Agustang, A. (2017). Sufisme dan Kemiskinan Kultural pada Komunitas Nelayan di Pesisir Teluk Bone Kecamatan Sibulue.

Agustang, A. (2006). Defleksi Sosio-Kultural Masyarakat Maritim Ke Arah Kepentingan Pembangunan (Studi Kasus Pada Komunitas Nelayan di Kabupaten Selayar Provinsi Sulawesi Selatan). Disertasi. Program Pascasarjana Universitas Padjajaran. Bandung.

Agustang, A. (2020, October). Social Actions of Galla Actors in the Kaemba Maros Traditional Village Community Sulawesi Selatan. In 3rd International Conference on Social Sciences (ICSS 2020) (pp. 748-753). Atlantis Press.

Agustang, A. (2021, January 9). KESEJAHTERAAN PSIKOLOGIS (Studi Pada Dewasa Madya yang Belum Menikah di Kota Makassar). https://doi.org/10.31219/osf.io/v5af8

Agustang, A., \& Asrifan, A. (2021, January 9). BAHAN MATA KULIAH MATA KULIAH PSYCHOLINGUISTICS. https://doi.org/10.31219/osf.io/n8j6t

Agustang, A., Suardi, I. A. M., Mutiara, I. A., \& Ramlan, H. (2020). SOCIAL PRENEUR DALAM PENANGGULANGAN KEMISKINAN DI KECAMATAN BISSAPPU KABUPATEN BANTAENG. Martabe: Jurnal Pengabdian Kepada Masyarakat, 3(2), 331-342.

Agustang, A., ORUH, S., \& ASRIFAN, A. (2021). PENGARUH PENGETAHUAN KELUARGA, STIGMA MASYARAKAT DAN KEPATUHAN MINUM OBAT TERHADAP KEKAMBUHAN PENYAKIT GANGGUAN JIWA DI KOTA MAKASSAR. OSF Preprints. January, 9.

Astinah, A., Idris, R., \& Agustang, A. (2020). AGILE LEADERSHIP AND DIVORCE 
EDUCATION: STUDY ON WOMEN'S PERCEPTION. Humanities, 8(3), 323-330

Arwan, A., Agustang, A., Arlin, A., Yani, A., \& PUTRA, D. M. (2019). Contestation of Elite Discourse in Treatment of HIV and AIDS. Iranian Journal of Public Health, 48(12), 2205.

Bob S Hadiwinata, The Politics of NGOs di Indonesia : Developing Democracy dan Managing a Movement : 2003.

Bruce J Cohen, 1992.Sosiologi Suatu Pengantar, Jakarta, Rineka Cipta,

Damami, Muhammad, 2004.Akar Gerakan Muhammadiyah, Yogyakarta :Fajar Pustaka.

David. 2002. Menuju Abad ke - 21 : Tindakan Sukarela dan Agenda Global.Yayasan Obor Indonesia: Jakarta.

Edgar F. Borgatta, 1992. Marei L Borgotta (et.al), Encyclopedia of sociology. Volume 4 (New York :MacMillan Publishing Company,) hal 1880.

Edy Suandi Hamid (Ed) .2001. Rekontruksi Gerakan Muhammadiyah Pada Era Multi Peradaban. Yogyakarta : Pimpinan Pusat Muhammadiyah.

Gettys, W. E., et. 1989. Al. Classical Physics and Modern. Mc Grawn - Hill Book Company,

Giddens, Anthony. 1979. Cultural Problems in Social Theory. London: Macmillan

Heldman, D.R. and R.P. Singh. 2001. Introduction to Food Engineering. London:Academic Press.

Mutiara, I. A., Agustang, A., Adam, A., Upe, A., \& Equatora, M. A. (2020). The dynamics of prostitutes lives in metropolitan cities. Journal of Critical Reviews. https://doi. org/10.31838/jcr, 7, 165 .

M, Hasim. 2006. Pendidikan Kewarganegaraan. Jakarta: Quadra

Pannyiwi, R., Agustang, A., Kasnawi, T., Pada, A. T., Yani, A., \& Syam, S. (2020). Social Network for Drug Circulation in Sidenreng Rappang Regency, Indonesia. Systematic Reviews in Pharmacy, 11(9), 575-577.

Rieuwpassa, S., Agustang, A., \& Adam, A. Sustainable Peace Development In Ambon (An Analysis Study In Negeri Hila And Dusun Hila Tanah Putih).

Sapulette, A. A., Agustang, A., \& Syukur, M. Actor Construction in the Frame of Diversity to Achieve Social Harmony in the Life of Tamilouw Village Society Seram Island-Maluku.

Tilome, A. A., Agustang, A., Jasruddin, M. S., \& Asrifan, A. (2020). Social Exchange of Political Elites in the Regional Leader Election of Gorontalo Province, Indonesia. Solid State Technology, 63(5), 521-531.

Upe, A., Salman, D., \& Agustang, A. (2019). The effects of the exploitation of natural resources towards risk society construction in Southeast Sulawesi Province, Indonesia. Journal of Degraded and Mining Lands Management, 6(2), 1587.

Awaru, A. O. T., Idris, R., \& Agustang, A. (2018, October). Sexual Education at High School Sinjai East. In 1st International Conference on Social Sciences (ICSS 2018). Atlantis Press.

Idris, M., Ramli, M., Agustang, A., \& Kesuma, A. I. (2015). Bureaucracy Ethics Based in Public Service Local Wisdom in Gowa. Mediterranean Journal of Social Sciences, 6(6 S4), 419-419.

Agustang, A., Pada, A. T., \& Bastiana, M. (2018, October). Social Interaction of Local Communities With Migrants and Changes in The Structure of Local Communities (Study on Plural Society in Makassar Industrial Area). In 1st International Conference on Social Sciences (ICSS 2018). Atlantis Press.

Wardah, S., Salman, D., Agustang, A., \& Fahmid, I. M. (2017). The Contestation of Organic and Non-Organic Agricultural Knowledge in Sustainable Agriculture. Mediterranean Journal of Social Sciences, 8(2), 245-245.

Agustang, A. (2018). SIMBOLIKHAJI: Studi Deskriptif Analitik pada Orang Bugis. AlQalam, 15(2), 317-334.

Pannyiwi, R., Agustang, A., Kasnawi, T., Pada, A. T., Yani, A., \& Syam, S. (2020). Social Network for Drug Circulation in Sidenreng Rappang Regency, Indonesia. Systematic Reviews in Pharmacy, 11(9), 575-577.

Agustang, A., \& Soelthan, A. (2015). Analysis of the Inhibiting Factors of Transparency in the Implementation of Local Governance. Mediterranean Journal of Social Sciences, 6(6 S4), 464.

Nain, U., \& Agustang, A. (2020). Analysis On The Utilization Of Village Funds In Cash For Work Program In Bulukumba Regency, South Sulawesi Indonesia. International Journal of Advanced Science and Technology, 29(7s), 2811-2818. 
Azis, F., Idris, R., \& Agustang, A. (2017). Involution Fisheries: Post-Study Model of National Program in Integrated Movement at Community Fishermen's Village Development Arungkeke, Jeneponto. Mediterranean Journal of Social Sciences, 8(1), 441.

Agustang, A. D. M. P., \& Nur, H. (2020). Konflik Mahasiswa Parang Tambung Universitas Negeri Makassar. Phinisi Integration Review, 3(1), 46-54.

Rasyid, R., Agustang, A., Maru, R., Agustang, A. T. P., \& Sudjud, S. (2020). PENYULUHAN PENCEGAHAN PENYALAHGUNAAN NARKOBA DI KALANGAN PELAJAR SMP NEGERI 6 DUAMPANUA KABUPATEN PINRANG. JMM (Jurnal Masyarakat Mandiri), 4(2), 116-123.

Rahmania, S., \& Agustang, A. (2017). PRESEPSI MAHASISWA FIK TERHADAP PENYIMPANGAN SEKSUAL LESBIAN (STUDI KASUS PADA MAHASISWA FIK UNM). JURNAL SOSIALISASI, 162-168.

Ashar, A., \& Agustang, A. (2020). Dampak Sosial Dana Desa Dalam Kesejahteraan Masyarakat Di Desa Kalola, Kecamatan Maniangpajo, Kabupaten Wajo. Jurnal Sosialisasi: Jurnal Hasil Pemikiran, Penelitian dan Pengembangan Keilmuan Sosiologi Pendidikan, (1), 19-25.

Yusuf, M., \& Agustang, A. (2020). DINAMIKA PERUBAHAN SOSIAL EKONOMI PADA MASYARAKAT KINDANG KABUPATEN BULUKUMBA. Jurnal Sosialisasi: Jurnal Hasil Pemikiran, Penelitian dan Pengembangan Keilmuan Sosiologi Pendidikan, (2), 31-37.

Fransina, M., \& Andi, A. (2019). THE ANALYSIS OF EXISTENCE OF MIGRATION IN THE CONTEXT OF BASUDARA COMMUNITY IN AMBON CITY, INDONESIA. Russian Journal of Agricultural and Socio-Economic Sciences, 94(10).

Usman, A., Agustang, A., Djalal, D., \& Annas, S. (2018, October). The Contribution Of Supporter Community In Maximizing Their Role For The Advancement Of Makassar Football Club (PSM). In 1st International Conference on Social Sciences (ICSS 2018). Atlantis Press.

Agustang, A., \& Oruh, S. Factors affecting of heropnam of mental disorders in Dadi Regional Hospital in South Sulawesi Province. Man In India, 97(11), 233-244.

Pratiwi, E. L., \& Agustang, A. (2018). PERSEPSI ORANGTUA SISWA TERHADAP TINDAKAN GURU DALAM MENDISIPLINKAN SISWA DI SMK YPKK LIMBUNG. JURNAL SOSIALISASI, 6-10.

Asri, A., Kasnawi, T., \& Agustang, A. Actors' Social Tensions on Traditional Birth Attendants and Midwife Partnerships in Childbirth Assistance (Sociology of Health Study in Bulukumba Regency).

Bahri, S., Kasnawi, T., Agustang, A., \& Adam, A. (2017). Vegetarian Community Social Movement (Analysis of Health Sociology in Makassar). The Social Sciences, 12(10), 1824-1831.

Djalante, A., Agustang, A., Tahmir, S., \& Sahabuddin, J. A Disadvantaged Tribe in Bajoe Village, Bone Regency: A Phenomenological Research on Bajo Tribe's Social Life in Bone Regency, South Sulawesi.

Rahmawati, R., \& Agustang, A. (2018). PERBANDINGAN POLA ASUH ORANG TUA SISWA BERPRESTASI DENGAN SISWA YANG TIDAK BERPRESTASI DI SMA NEGERI 2 GOWA. JURNAL SOSIALISASI, 115-119.

Agustang, A. (2018). PERAN WALI KELAS DALAM PENYELESAIAN KONFLIK ANTAR SISWA DI SMA NEGERI 1 PINRANG. JURNAL SOSIALISASI, 12-16.

Irnawaty, I., \& Agustang, A. (2019). SMARTPHONE ADDICTION PADA MAHASISWA PENDIDIKAN SOSIOLOGI FAKULTAS ILMU SOSIAL UNIVERSITAS NEGERI MAKASSAR. JURNAL SOSIALISASI, 41-46.

Zainuddin, M., \& Agustang, A. (2019). KONTROL SOSIAL ORANGTUA TERHADAP PENGGUNAAN SMARTPHONE PADA REMAJA (STUDI DI DESA GIRING-GIRING KECAMATAN BONTONMPO KABUPATEN GOWA. JURNAL SOSIALISASI, 68-73.

Sofyan, Y., \& Agustang, A. (2018). PENERAPAN MODEL PEMBELAJARAN KOOPERATIF TIPE NHT (NUMBERED HEADS TOGETHER) TERHADAP KEAKTIFAN BELAJAR SISWA KELAS XI IPS 1 SMAN 8 MAKASSAR. JURNAL SOSIALISASI, 158-165.

Agustang, A. (2018). PENERAPAN PUNISHMENT DALAM MEMBENTUK KARAKTER DISIPLIN SISWA DI SMA NEGERI 1 TAKALAR. JURNAL SOSIALISASI, 126-130.

Amiruddin, T. K., Agustang, A., \& Idris, R. (2014). RELIGIOUS CONVERSION IN MARRIED 
LIFE IN MAKASSAR, THE CASE OF CHRISTIANITY TO ISLAM. JOURNAL OF ACADEMIC RESEARCH, 6(6), 264.

Machmuddin, H., Agustang, A., Kahar, F., \& Bustan, N. (2015). IMPROVING THE QUALITY OF PRIMARY HEALTH SERVICES IN THE PERSPECTIVE OF PARTICIPATORY GOVERNANCE. International Journal of Academic Research, 7(1).

Agustang, A., \& Sahabuddin, J. (2020, October). MODEL KOLABORASI SOSIAL PENDIDIKAN KARAKTER DI SEKOLAH SWASTA KECAMATAN BISSAPPU KABUPATEN BANTAENG. In PROSIDING SEMINAR DAN DISKUSI PENDIDIKAN DASAR.

Astinah, A., Idris, R., \& Agustang, A. (2020). AGILE LEADERSHIP AND DIVORCE EDUCATION: STUDY ON WOMEN'S PERCEPTION. Humanities, 8(3), 323-330.

Muis, I., Agustang, A., \& Adam, A. (2020). Elderly Poverty: Social Demographic, Work Distribution, Problem Health \& Social Protection. Asian Journal of Social Sciences \& Humanities Vol, 9(1).

Agustang, A. (2020). Symbolic Violence towards Students in the Context of the Existence of the Stereotypical Frames of Lecturers and Students in the Higher Education System in Indonesia. PalArch's Journal of Archaeology of Egypt/Egyptology, 17(2), 249-258.

Asrifan, A. (2009). Using songs in teaching English language for the young learners. ParePare: unpublished.

Puasa, K., Asrifan, A., \& Chen, Y. (2017). Classroom Talk in Bilingual Class Interaction. Research in Pedagogy, 7(1), 106-121.

Nadirah, N., Tahir, M. H., \& Asrifan, A. (2019). THE ABILITY TO TRANSLATE ENGLISH PHRASES INTO INDONESIAN AND THE DIFFICULTIES FACED BY THE ELEVENTH GRADE STUDENTS OF SMAN 1 PANCARIJANG. JOURNAL OF ADVANCED ENGLISH STUDIES, 2(1), 41-46.

Apdy, A. P. R., \& Asrifan, A. (2019, April). The Chinese mime game in teaching vocabulary on EFL classroom. In PROCEEDINGS OF THE 65th TEFLIN INTERNATIONAL CONFERENCE (Vol. 65, No. 01).

Taslim, T., Asrifan, A., Chen, Y., \& Nurdania, N. R. (2019). CORRELATION BETWEEN STUDENT'S VOCABULARY MASTERY AND SPEAKING SKILL. JOURNAL OF ADVANCED ENGLISH STUDIES, 2(2), 65-76.

Muthmainnah, M., Asrifan, A., Al Yakin, A., \& Sahabuddin, C. (2019, April). The use of dictogloss technique on ELT classroom: An experiment study of students listening comprehension. In PROCEEDINGS OF THE 65th TEFLIN INTERNATIONAL CONFERENCE (Vol. 65, No. 01).

Mutmainnah, M., Azis, S., Maulidya, U., \& Asrifan, A. (2017). Glory Style in Mandar Song Lyrics: A study of Mandar Tribe in South Sulawesi, Indonesia. JOURNAL OF ADVANCES IN LINGUISTICS, 8(1), 1286-1291.

Asrifan, A., Rinantanti, Y., Tang, S., \& Nadirah, N. (2019). THE 3-DIMENSION PICTURES IN INCREASING THE STUDENTS ABILITY AND INTEREST TO WRITE DESCRIPTIVE COMPOSITION. JOURNAL OF ADVANCED ENGLISH STUDIES, 2(1), 19-30.

Asrifan, A., Nadira, N., \& Haedar, H. (2018). IMPROVING STUDENTS'READING COMPREHENSION OF DESCRIPTIVE TEXT THROUGH COLLABORATIVE MURDER. JOURNAL OF ADVANCED ENGLISH STUDIES, 1(2), 21-31.

Asrifan, A. (2015). Analysis of English Students' Learning Style in Bilingual Class. International Journal of Literature and Arts, 3(4), 34.

Farahdiba, S., \& Asrifan, A. (2016). Speaking Ability and Psychological Barriers of the Second Year Students of Hotel Department of SMKN 1 Sidenreng Kabupaten Sidrap in Speaking English. Asian EFL Journal, (89), 41.

Asrifan, A. (2012). Increasing the Students Ability to Write Descriptive Composition at SMP Negeri 13 Parepare by using the 3-Dimension Pictures.

Tang, S., Asrifan, A., Chen, Y., Haedar, H., \& Agussalim, M. (2019). THE HUMOR STORY IN TEACHING READING COMPREHENSION. JOURNAL OF ADVANCED ENGLISH STUDIES, 2(2), 77-87.

Nurwanti, N., Asrifan, A., \& Haedar, H. (2019). THE APPLICATION OF COOPERATIVE LEARNING: JIGSAW II TECHNIQUE IN IMPROVING STUDENTS'READING 
COMPREHENSION OF EXPOSITORY TEXT. JOURNAL OF ADVANCED ENGLISH STUDIES, 2(1), 31-40.

Asrifan, A. (2016). The Effectiveness of Think-Pair-Share Technique in Improving Studentsâ€TM Speaking Ability and Interest. English Literature and Language Review, 2(3), 24-35.

Asrifan, A., Muthmainnah, M., Al-Yakin, A., Sahabuddin, C., \& Haedar, H. (2018). THE CAUSEEFFECT TECHNIQUE IN TEACHING RECOUNT WRITING. JOURNAL OF ADVANCED ENGLISH STUDIES, 1(2), 63-72.

Asrifan, A., Vargheese, K. J., Syamsu, T., \& Amir, M. (2020). ESP COURSE DESIGN: THE NEED ANALYSIS ON TOURISM DEPARTMENT IN INDONESIA VOCATIONAL HIGH SCHOOLS. JOURNAL OF ADVANCED ENGLISH STUDIES, 3(2), 69-77.

Asrifan, A., Ghofur, A., \& Azizah, N. (2020). Cheating Behavior in EFL Classroom (A Case Study at Elementary School in Sidenreng Rappang Regency). OKARA: Jurnal Bahasa dan Sastra, 14(2), 279-297.

Nadirah, N., Asrifan, A., Vargheese, K. J., \& Haedar, H. (2020). INTERACTIVE MULTIMEDIA IN EFL CLASSROOM: A STUDY OF TEACHING READING COMPREHENSION AT JUNIOR HIGH SCHOOL IN INDONESIA. JOURNAL OF ADVANCED ENGLISH STUDIES, 3(2), 131-145.

Muthmainnah, A. R., Atmowardoyo, H., Salija, K., \& Asrifan, A. (2020). Literary Work as Teaching Materials: A Study of Students and Lecturers Needs Analysis. Solid State Technology, 63(5), 394-407.

Tilome, A. A., Agustang, A., Jasruddin, M. S., \& Asrifan, A. (2020). Social Exchange of Political Elites in the Regional Leader Election of Gorontalo Province, Indonesia. Solid State Technology, 63(5), 521-531.

Pacinongi, A., \& Asrifan, A. (2020). Bimbingan Pengawas Berkelanjutan dalam Mewujudkan Pendidikan Karakter Bangsa dalam Kegiatan Belajar Mengajar Penjaskes. Celebes Education Review, 2(1), 1-7.

Gunawan, G., \& Asrifan, A. (2020). Penerapan Kerja Kelompok Kegiatan MGMP Guru Ekonomi dalam Menyusun RPP untuk Meningkatkan Kompetensi Pedagogik. Celebes Education Review, 2(1), 31-36.

Yusuf, I., \& Asrifan, A. PENINGKATAN AKTIVITAS KOLABORASI PEMBELAJARAN FISIKA MELALUI PENDEKATAN STEM DENGAN PURWARUPA PADA SISWA KELAS XI IPA SMAN 5 YOGYAKARTA. Editorial Team, 32.

Al Yakin, A., Sahabuddin, C., Rahayu, A., Fitrah, N., \& Arifin, M. (2020). Political Celebrification and Electability: A Study of Political Phenomena Imaging in Election Polewali Mandar District, West Sulawesi, Indonesia. Solid State Technology, 63(5), 632-646.

Junaedah, S. B. T., \& Ahmad, M. A. (2020). The Outdoor Learning Modules Based on Traditional Games in Improving Prosocial Behaviour of Early Childhood. International Education Studies, 13(10).

Octaberlina, L. R., \& Muslimin, A. I. (2020). Efl students perspective towards online learning barriers and alternatives using moodle/google classroom during covid-19 pandemic. International Journal of Higher Education, 9(6), 1-9.

Octaberlina, L. R., \& Anggarini, I. F. (2020). Teaching vocabulary through picture cards in Islamic Elementary School: a case study in Nida Suksa School, Thailand. Jurnal Madrasah, 13(1), 2638.

Octaberlina, L. R. (2016). Plagiarism in English language theses in Indonesia. Jurnal Ilmu Pendidikan, 14(3).

Octaberlina, L. R., \& Anggarini, I. F. (2020). Teaching vocabulary through picture cards in Islamic Elementary School: a case study in Nida Suksa School, Thailand. Jurnal Madrasah, 13(1), 2638.

Asrifan, A., Zita, C. T., Vargheese, K. J., Syamsu, T., \& Amir, M. (2020). THE EFFECTS OF CALL (COMPUTER ASSISTED LANGUAGE LEARNING) TOWARD THE STUDENTS'ENGLISH ACHIEVEMENT AND ATTITUDE. JOURNAL OF ADVANCED ENGLISH STUDIES, 3(2), 94-106.

Asrifan, A. (2021). ACADEMIC WRITING. LawArXiv. January, 2. 
https://doi.org/10.31228/osf.io/x2s7e

Asrifan, A. (2020). TUTORIAL PENGGUNAAN QUIZIZZ (www. quizizz. com) PADA PEMBELAJARAN. https://doi.org/10.31219/osf.io/kqnza

Asrifan, A. (2021). Abd Ghofur.“. THE USE OF READING CIRCLES IN INCREASING STUDENTS SPEAKING ABILITY AT THE ELEVENTH GRADE SMK NEGERI, 1. https://doi.org/10.31219/osf.io/8vjxy

Asrifan, A. (2020). Pandemic, Humanity and Education. https://doi.org/10.31219/osf.io/q2gpk

Asrifan, A. (2021). USING CAT AND MOUSE GAME TO IMPROVE STUDENT'S SPEAKING ABILITY AT THE ELEVENTH GRADE OF MA YMPI RAPPANG. https://doi.org/10.31219/osf.io/phtvn

Asrifan, A., \& Ghofur, A. (2021). THE USE OF READING CIRCLES IN INCREASING STUDENTS SPEAKING ABILITY AT THE ELEVENTH GRADE SMK NEGERI 1 PANCARIJANG. https://doi.org/10.31219/osf.io/8vjxy

Asrifan, A. (2021). Book Review: Halliday. 1989. Spoken and Written Language. Oxford University Press. https://doi.org/10.31219/osf.io/ej8tb

Asrifan, A., \& Ghofur, A. (2021). TALK, ACTION, SILENCE, INTERRUPTION AND THEIR IMPLICATIONS IN BUGINESE SOCIETY (SOPPENG REGENCY). https://doi.org/10.31219/osf.io/pv3ku

Asrifan, A. (2020). PENILAIAN BERBASIS ANDROID MENGGUNAKAN APLIKASI PLICKERS. https://doi.org/10.31219/osf.io/htreq

Haulussy, R. H., Najamuddin, I. R., \& Agustang, A. D. M. P. (2020). The sustainability of the Sasi Lola tradition and customary law (Case study in Masawoy Maluku, Indonesia). Intl J Sci Technol Res, 9(2), 5193-5195.

Arwan, A., Agustang, A., Arlin, A., Yani, A., \& PUTRA, D. M. (2019). Contestation of Elite Discourse in Treatment of HIV and AIDS. Iranian Journal of Public Health, 48(12), 2205.

Mutiara, I. A., Agustang, A., Adam, A., Upe, A., \& Equatora, M. A. (2020). The dynamics of prostitutes lives in metropolitan cities. Journal of Critical Reviews. https://doi. org/10.31838/jcr, 7, 165.

Usman, A., Agustang, A., Djalal, D., \& Annas, S. (2018, October). The Contribution Of Supporter Community In Maximizing Their Role For The Advancement Of Makassar Football Club (PSM). In 1st International Conference on Social Sciences (ICSS 2018). Atlantis Press.

Ma'na, P., Agustang, A., Salusu, J., Ikhsan, A., \& Dirawan, G. D. (2015). Decision making strategic value based local wisdom Tongkonan North Toraja. Man India, 95(3), 633-639.

Dirawan, G. D. FOSTERING COLLABORATION STREET CHILDREN IN MAKASSAR. Man In India, 95(3), 569-576.

Abdurachman, A. D. M. P. A., \& Agustang, A. Culture Of Shame-Heart And Social Solidarity Of Kaitetu People Central Maluku District, Indonesia.

Aida, K. N., Agustang, A., Arlin, A., \& Agustang, A. D. M. The Patron-Client Relationship Patterns In Siwa Lima Fishermen Community, Aru Islands District Maluku, Indonesia.

Pannyiwi, R., Agustang, A., Kasnawi, T., Pada, A. T., Yani, A., \& Syam, S. (2020). Social Network for Drug Circulation in Sidenreng Rappang Regency, Indonesia. Systematic Reviews in Pharmacy, 11(9), 575-577.

Upe, A., Salman, D., \& Agustang, A. (2019). The effects of the exploitation of natural resources towards risk society construction in Southeast Sulawesi Province, Indonesia. Journal of Degraded and Mining Lands Management, 6(2), 1587.

Matakena, F., Watloly, A., Agustang, A., Adam, A., \& Alim, A. (2020). The Self-Concept of Ale Rasa Beta Rasa in the Orang Basudara Community in Ambon (Studies on the Community of Passo and Batumerah Country). International Journal, 9, 1307.

Asmi, A. S., Kasnawi, M. T., Agustang, A., \& Yani, A. (2020). Sociocultural Transformation in Efforts to Reduce Mortality of Infants in Bone Regency, Indonesia. Systematic Reviews in Pharmacy, 11(10), 762-765.

Usmana, A., \& Agustangb, A. The Implementation of "Arif" Social Behaviour within Perssin Supporters in Sinjai District.

Hasan, I. R., Agustang, A., Kahar, F., \& Tahir, H. (2019). Super Service Delivery”: an advanced 
conceptual model of one-stop service for wide administrative region. Problems and perspectives in management, (17, Iss. 1), 189-201. 
